Ethiopian Journal of Environmental Studies \& Management 7(2): 108 - 116, 2014.

ISSN:1998-0507

doi: http://dx.doi.org/10.4314/ejesm.v7i2.1

Submitted: March 27, 2013

Accepted: February 25, 2014

\title{
THE IMPACT OF NOISE AND DUST LEVEL ON RENTAL PRICE OF RESIDENTIAL TENEMENTS AROUND LAFARGE CEMENT FACTORY IN EWEKORO TOWN, NIGERIA
}

*KEMIKI, O. A., OJETUNDE, I. AND AYOOLA, A.B.

Department of Estate Management and Valuation, School of Environmental Technology, Federal University of Technology, Minna P.M.B. 65 Minna, Nigeria.

\begin{abstract}
This study employed hedonic pricing model to investigate the impact of noise and dust spewed from a cement factory on a sample of 126 tenements from 11 residential settlements within Ewekoro local housing market in Nigeria. Market-wide hedonic model for all the 126 tenements within $5.5 \mathrm{~km}$ of the cement factory) was estimated. In addition, two separate unrestricted hedonic models were also estimated (the first consisting of 38 tenements within $2.5 \mathrm{~km}$ of the factory and the other comprising 88 tenements located between $2.5 \mathrm{~km}$ to $5.5 \mathrm{~km}$ of the factory). The hedonic models which take the doublelog functional form were estimated with house rent (a proxy for house price) as the dependent variable. Generally, the results of the market-wide model revealed that, dust level and noise, which are negative externalities from the cement factory dampen rent by 21.90\% ( $\$ 13815$ ) and 1.49\% ( 24.80 ) respectively within the study area. Findings from the unrestricted models further signify that tenement rents tend to decrease with increasing distance to Lafarge cement factory due to severity of dust and noise. As panacea to this problem it is recommended that government should provide policy response - the introduction of effluent fees which would force the cement and other manufacturing companies to internalize their externalities by paying for noise and dust pollution. The basic objective of such policy response is for manufacturing companies to move to the use of energy efficient and eco-friendly plants that generate less noise and dust in their production operations. On the other, the cement company should also imbibe Corporate Social Responsibility (CSR) as part of its efforts in providing a sustainable living environment for the residents in Ewekoro town.
\end{abstract}

Key words: Cement factory, Externalities, Hedonic modelling, Tenements, Settlements.

\section{Introduction}

The contribution of industry to local and national economy in all facets is not in doubt as it is one of the key drivers of economic growth and development. The impact of industrial activities is felt in a variety of ways. Presence of industries in any community most especially large scale industries such as textile, automobile and cement confer external benefits in the area of employment generation, infrastructural provision, and boost in the residents' socialeconomic status. Others include population upsurge, expansion of local market, increased demand for accommodation, vibrant real property development and consequently increase in property value. In terms of land use, while these industries may produce goods and services that are beneficial to a segment of the population, the property values of others may be diminished (Ling and Archer, 2005).

Concerns have been expressed over the years on the negative impact of industries, most especially, on the host communities (Louw et al., 2003; and Louw et al., 2004). A range of

*Corresponding Author: Kemiki, O.A.

Email: kemiki@futminna.edu.ng external costs is associated with manufacturing industries, the most prominent impacts being noise and loss of visibility resulting from dust and gaseous emissions. Externalities on land use such as unwanted noise and dust spewed from manufacturing industries alter the existing way of life of the people and the value of surrounding properties. From a welfare view point, these negative impacts are often neglected or not captured properly when evaluating costs and benefits of such externalities to the host communities. A tenable reason is that pricing externalities is difficult, because by their very nature, they are nonmarketable environmental goods whose prices are quite unobservable relative to a marketable/investment product whose price are readily observable.

One of such special marketable commodities is housing, which aside from being a consumption goods, its ownership is an investment for which the owner-occupier receive an attractive and positive return in form of rent and price in event of sale (Hutchison 
1994). Distilling the impact of such externalities entail determining their contribution to the price of this special commodity ( housing) that shape the attitude of individuals and groups and which in turn influences neighbourhood and environmental characteristics. A commonly employed technique for pricing externalities is hedonic pricing model developed by Rosen (1974). The model is based on the fact that the relative price of a typical house can be determined by regressing the physical, location and neighbourhood attributes of an area's house stock to estimates the regression coefficients (the characteristic prices) which can be summed up to give the aggregate price of the house.

Several contributions from published literature have considered the extent to which environmental goods act as potential predictors of house prices. A classical and clear-cut classification of these is in the review of literature provided in Boyle and Kiel (2001) study. To start with, Benjamin and Sirmans (1996) considered the impact of neighbourhood variables such as noise from public transportation facilities and airport on house prices. Findings from their study showed that rent of apartments located near Washington DC metro station decrease by $2.4 \%$ to $2.6 \%$ for every 0.1 mile increase in distance away from the station. Earlier studies of this nature by O'Byrne et al. (1985) and Hamilton and Biggs (1993) have also shown that airport noise impact largely and have statistically significant negative effect on house prices.

In discussions relating to the effect of externalities such as air quality on house prices, Palmquist (1982) used housing and neighbourhood attributes of twenty metropolitan areas in USA together with pollution variables such as total suspended particulate, nitrogen dioxide, ozone and sulphur as independent variables. The results of the hedonic regression revealed that the actual signs and statistical significant level of the estimated pollution coefficients were not consistent across the study area (for instance, total suspended particulate was only negative and statistically significant in 6 out of 20 metropolitan areas while the ozone was only negative in 8 of the 12 metropolitan areas and only statistically significant in 6 metropolitan areas). This he argued was due to omission of location variables from the variables that entered the hedonic model. Extending his study, Palmquist (1983) included location variable of fourteen cities and data on local property taxes and also derived a pollution index for the pollution variables employed in his earlier study. Finding from the study was however a bit consistent, as the pollution coefficients were negative and statistically significant in six out of the fourteen cities of the study area. Zable and Kiel (2000) study however produced a similar but convincing result with eighteen out of the twenty- three pollution coefficients estimated being negative and significant.

Thayer et al. (1992) employed multiple but different environmental pollution variables (ozone, sulphur dioxide, nitrogen oxide and particulate matter) together with other housing and neighbourhood data. They uncovered the effects of air quality and proximity to waste sites on house prices. They tested their linear and semi-log hedonic model specifications by including measures of air quality. Results revealed that only the ozone variable was consistent (with other variables removed) and that $6 \%$ improvement in air quality increases house price by $\$ 3481$. In addition, increase in distance by one mile from the waste site increases property price by $\$ 1349$ in the linear specification and \$1701 in the semi-log form.

They further estimated two models to determine the distance break points at which the impact of waste fizzle out on house prices. The first model was specified by grouping properties into categories of less than waste site and assigning 1 to 3 respectively to this categorisation. It was found that further movement away into another distance category increased house value by $\$ 4380$ in the linear model and $\$ 5320$ in the semi-log model. Secondly, using zero or one dummy variables for the distance categories, they also found that home in the second category based on distance has a value of $\$ 11,500$ more than a home in the first category and that a house in the third category has a value of $\$ 2400$ more than a house in the second category. Again by comparing hazardous and non-hazardous sites Thayer et al. concluded that increase in price as a result of one mile increase away from hazardous sites was not due to health risk but aesthetics.

This paper is an extension of few earlier studies such as Thayer et al. (1992) as it includes multiple environmental variables (dust level and noise) in addition to housing and neighbourhood data as the variables for study. The inclusion of these two environmental variables as part of the variables on the right hand side of the hedonic model would reduce omitted variable bias and produce robust estimated coefficients as suggested in Leggett 
and Bockstaael (2000) study. Previous studies have however distilled the impact of these environmental variables by focusing of house sale price (as dependent variable) which in most cases exhibit unobservable random noise that cause such price to differ from the true market price.

The present study instead of using house sale price (as the dependent variable) contributes to the understanding of how externalities such as dust and noise can be effectively priced by using house rent which has remained a significant feature of most markets for housing services in the world. Against this backdrop important research questions which merit academic and public policy considerations and which is the focal point of this paper are: do noise and dust level from manufacturing industries (cement factory) constitute significant predictors of house rents (a surrogate for prices)? What is the contribution of externalities (in this case noise and dust level) to the price of housing? In other words, to what extent do negative externalities (such as noise and dust level) from the factory dampen house rents? Do noise and dust level cause house rents to fizzle out with increasing distance (in Kilometres) from the cement factory?

\section{Materials and Methods}

Lafarge manufacturing cement is sited in Ewekoro town. The town itself is located in Ogun State which is in the South Western part of Nigeria (figure 1). The town which can be accessed via Abeokuta - Lagos road lies on $6^{\circ}$ $58^{\prime} 30^{\prime \prime}$ North and longitude of $3^{\circ} 15^{\prime} 30^{\prime \prime}$ East and $6^{\circ} 51^{\prime} 30^{\prime \prime}$ North and longitude of $3^{\circ} 15^{\prime}$ $30^{\prime \prime}$ East. It has an area of $631.5 \mathrm{~km}^{2}$. The climate of the area is influenced by the two major wind currents in Nigeria that is the South West which blows across the ocean and causes wet season and the North East wind blowing across which brings about harmattan (the dry wind). The average monthly temperature ranges from $23^{\circ} \mathrm{C}$ to $32.2^{\circ} \mathrm{C}$ (Meteorological Department Abeokuta, 2011).

The geological formation of the area shows that it is of sedimentary rock formation hence the presence of limestone deposits which is the major raw material in cement production. It is the presence of limestone deposits in commercial quantity that provides the economic base of the study area and drives its real estate activity and value. Unsurprisingly, a characteristic feature of the study area is the clear concentration of eleven (11) residential settlements (which are predominantly tenements) around the cement manufacturing factory.

Against this background, the main data for this study was therefore obtained by administering structured questionnaires to 126 tenements in the 11 residential settlements (Ewekoro, Itori, Alaguntan, Elebute, Egabado Ajegunle, Akinbo, Papalanto, Olapeleke, Araromi (Olujobi), Oko Eko Egabado and Oko Eko Sekoni) situated within the vicinity of Larfage cement factory. The breakdown of the tenements by settlement, the number of questionnaire administered and retrieved is reported in Table1. The data extracted from questionnaire survey of these tenements between January 2011 to August 2011 and pertain to house rent, physical characteristics, locational neighbourhood and environmental attributes of tenement property.

The data include house rent, condition of external wall and foundation, roofing condition, age of building, building area, distance of house to factory, distance of house to work place, occupation of household head, income of household head, dust and noise level from factory. Subsequently income and distance of house to work place variables were dropped to avoid multi-collinearity problems as both were correlated with occupation and distance to factory respectively. 


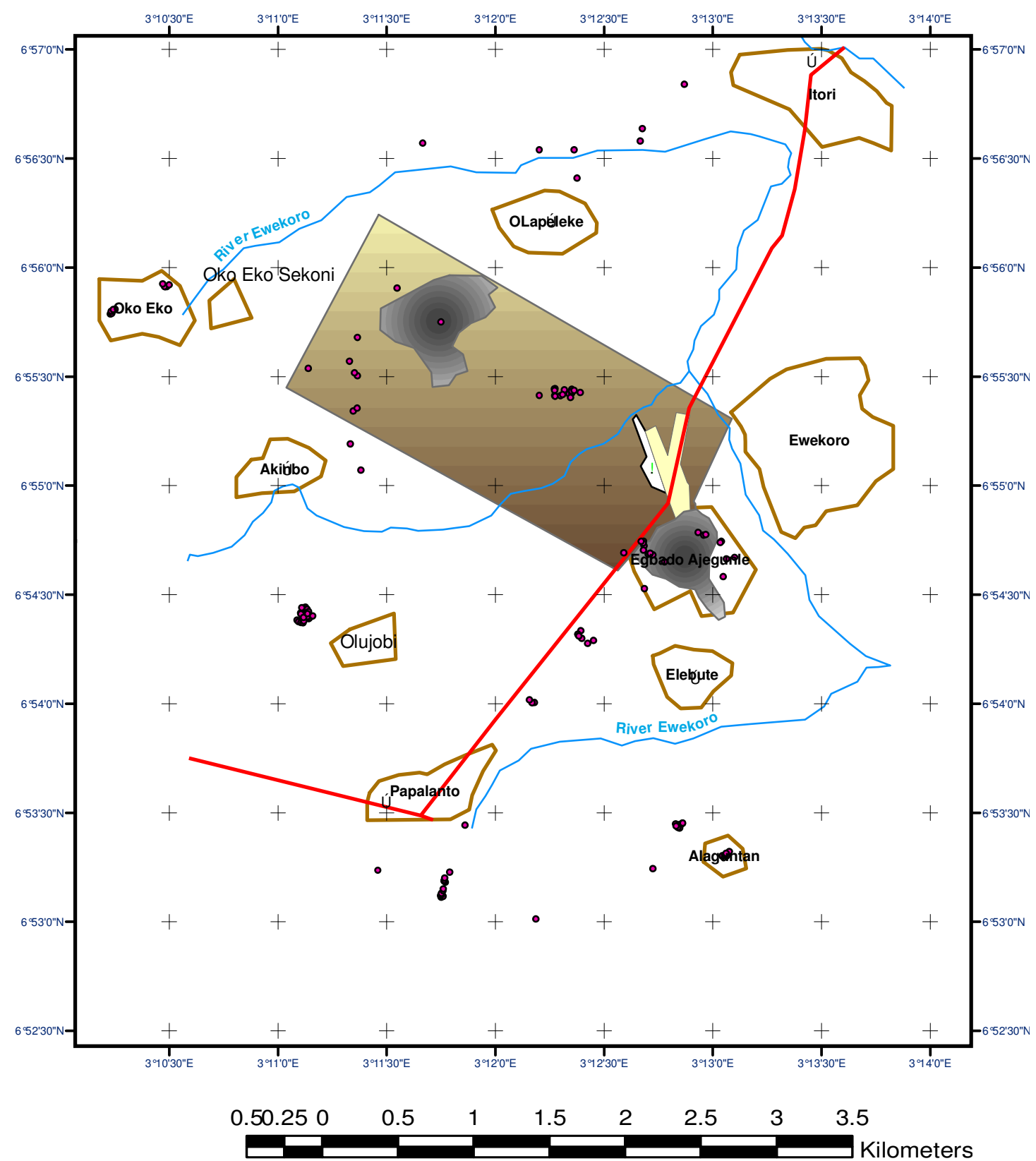

\section{Legend}

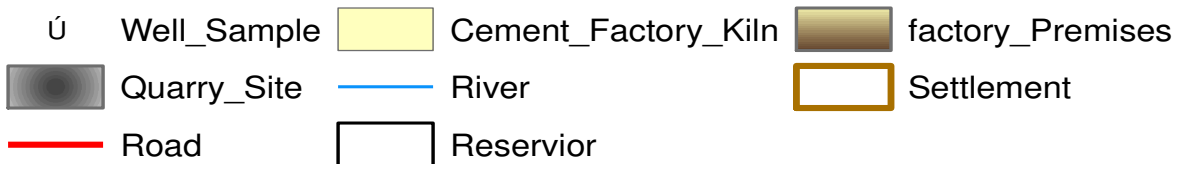

Figure 1: Map of Lafarge Cement Factory and the Residential Settlements 
Table 1: Breakdown of the Tenements and Questionnaire Administration.

\begin{tabular}{llllll}
\hline Residential Settlements & $\begin{array}{l}\text { Number } \\
\text { Tenements }\end{array}$ & of & $\begin{array}{l}\text { Number } \\
\text { questionnaire } \\
\text { Distributed }\end{array}$ & $\begin{array}{l}\text { of } \\
\text { Questionnaire } \\
\text { Returned }\end{array}$ & $\begin{array}{l}\text { of } \\
\begin{array}{l}\text { number } \\
\text { questionnaire } \\
\text { returned }\end{array}\end{array}$ \\
\hline Ewekoro & 38 & 38 & 13 & 34.2 \\
Akinbo & 15 & 15 & 7 & 46.6 \\
Araromi(Olujobi) & 19 & 19 & 10 & 52.6 \\
Papalantoro & 59 & 59 & 25 & 42.4 \\
Elebute & 19 & 19 & 12 & 63.2 \\
Alaguntan & 10 & 10 & 6 & 60 \\
OkoEkoEgbado & 9 & 9 & 7 & 77.7 \\
OkoEkoSekoni & 11 & 11 & 7 & 63.6 \\
Olapaleke & 21 & 21 & 13 & 61.9 \\
EgbadoAjegunle & 25 & 25 & 16 & 64.0 \\
Itori & 45 & 45 & 24 & 53.3 \\
\hline Total & 271 & 271 & 140 & 51.9 \\
\hline
\end{tabular}

Among the 140 questionnaire returned from the survey, 14 were dropped due to missing information. As a result, the empirical results of the hedonic models are subsequently presented based on 126 complete observations. The variables used, their description and descriptive statistics are presented in Table 2.

Table 2: Variable Used, Description and Descriptive Statistics

\begin{tabular}{|c|c|c|c|c|c|}
\hline Variables & Description & Mean & Maximum & Minimum & $\begin{array}{l}\text { Std. } \\
\text { Dev. }\end{array}$ \\
\hline AGE & Age of building (years) & 12.32 & 21.00 & 3.00 & 6.21 \\
\hline ANNUAL_RENT & House rent (per annum) & 147619 & $504000 *$ & $72000 *$ & 78710 \\
\hline BLD_AREA & Area of building (square metre) & 226 & 650.00 & 110.00 & 113.19 \\
\hline HOUSEDIST_TO_FACTORY & Distance of house to factory $(\mathrm{km})$ & 2.92 & 5.50 & 0.63 & 0.91 \\
\hline DUST_LEVEL & $\begin{array}{l}\text { Level and severity of dust from } \\
\text { factory** }\end{array}$ & 2.34 & 5.00 & 1.00 & 1.29 \\
\hline EXTERNAL_WALL_CONDN & $\begin{array}{l}\text { Condition of external wall. Dummy } \\
\text { equals to } 1 \text { if condition is good; } \\
\text { otherwise } 0\end{array}$ & 0.40 & 1.00 & 0.00 & 0.49 \\
\hline FOUNDN_CODN & $\begin{array}{l}\text { Condition of foundation. Dummy equals } \\
\text { to } 1 \text { if condition is good; otherwise } 0\end{array}$ & 0.50 & 1.00 & 0.00 & 0.50 \\
\hline NOISE_LEVEL & $\begin{array}{l}\text { Level and severity of noise from factory } \\
\text { (measured in decibel)*** }\end{array}$ & 88.46 & 103.00 & 30.00 & 16.65 \\
\hline OCCUPATION & occupation of household head & 3.09 & 7.00 & 1.00 & 1.31 \\
\hline ROOF_CONDN & $\begin{array}{l}\text { Condition of roof. Dummy equals to } 1 \text { if } \\
\text { condition is good; otherwise } 0\end{array}$ & 0.53 & 1.00 & 0.00 & 0.50 \\
\hline
\end{tabular}

* The high value in minimum and maximum rent is due to the quantum of the tenement. ** An index was derived for carbon monoxide, sulphur oxide and total particulate matters to measure the level and severity of dust and ranked as: $1=$ very low; $2=$ low; $3=$ fair; $4=$ high and $5=$ very high. $* * *$ The sound pressure level was measured at interval using Sound level meter with the intensity of sound measured in Decibels $d B(A)$. Where (A) denotes that the scale is adapted for the human hearing range. Decibel $\mathrm{Le}_{\mathrm{q}}=10 \log _{10} \mathrm{~L} / \mathrm{L}_{\mathrm{o} . \text {. }} \mathrm{Where}_{\mathrm{Le}}=$ Equivalent Noise Level; $\mathrm{L}=$ Sound Intensity and $\mathrm{L}_{\mathrm{o}}=$ Reference Level.

Table 2 shows that the tenements in the sample has a mean annual rent of about 147,619 and an approximate building area of 226 square metres with a mean age of over 12 years. An average tenement has an average distance of $2.92 \mathrm{~km}$ from the cement factory with the level and severity of noise and dust from the factory averaging 88.46 decibel and 2.34 (which is ranked relatively low) respectively. $40 \%$ of the tenements have their external walls in good condition. In addition, $53 \%$ of all these tenements have good quality roofs with $50 \%$ having good foundation.

The data were subjected to hedonic regression. The estimated hedonic models take the following double-log functional form in which all the variables, with the exception of dichotomous variables, are measured in logarithmic form:

$\operatorname{Ln}($ Annual Rent $)=\quad \beta_{1}+\delta_{1}$ Lnage $+\delta_{2}$ Ln building area +

$\delta_{3}$ Ln house-factory distance $+\delta_{4} \operatorname{Ln}$ occupation $+\delta_{5}$ Ln noise level +

$\gamma_{1}$ external wall condition $+\gamma_{2}$ foundation condition +

$\gamma_{3}$ roof condition $+\gamma_{4}$ dust level $+\varepsilon$

Where rent is expressed in its natural logarithm, $\beta_{1}$ is a constant term, the coefficients $\delta 1-\delta 5$ are the percentage change in rent 
resulting from a unit change in age, building area, house-factory distance, occupation and noise level respectively. The coefficients $\gamma_{1-} \gamma_{3}$ reveal the percentage change in rent of having external wall, foundation and roofing in good condition respectively. $\varepsilon$ is the uncorrelated residual term.

The market wide hedonic model was estimated for the 126 tenements employed in this study and includes all tenements within $5.5 \mathrm{~km}$ of the cement factory. In determining the impact of noise and dust level on house rents based on distance from the cement factory, a parameter stability test ( F or Chow Test) was used to determine if there is structural change in the estimated implicit prices of a hedonic model) This test split the rental data into two on the basis of those within $2.5 \mathrm{~km}$ of the factory and also those between $2.5 \mathrm{~km}$ to $5.5 \mathrm{~km}$ of the factory. It is this split that provided for two unrestricted models to be estimated.

In this case, the chow or F-test determines whether significant statistical difference exist between the implicit prices of tenements within $2.5 \mathrm{~km}$ of the factory and those tenements between $2.5 \mathrm{~km}$ to $5.5 \mathrm{~km}$ of the factory (See Gujarati 2003 and Brooks 2008).

The chow-test is derived based on the formula:

$$
F=\frac{R S S-\left(R S S_{1}+R S S_{2}\right)}{R S S_{1}+R S S_{2}} \times \frac{T-2 k}{k} \sim F[k, T-2 k]
$$

Where RSS $=$ residual sum of squared for the market wide model, $\mathrm{RSS}_{1}=$ residual sum of squared for unrestricted model $1, \mathrm{RSS}_{2}=$ residual sum of squared for unrestricted model $2, \mathrm{~T}=$ number of observations, $2 \mathrm{k}=$ number of coefficients estimated for the two unrestricted regressions, $\mathrm{k}=$ number of coefficients in each unrestricted regression.

In passing we set the following nondirectional hypothesis leading to a two tail test to determine the validity or otherwise of such structural change:

Ho: Price equality between the implicit price coefficients of house rent based on distance to factory is simultaneously equal to zero.

H1: Price equality between the implicit price coefficients of house rent based on distance to factory is not zero.

Finally, White (1980) heteroskedasticity test which is a general test for model misspecification is applied to the hedonic model to establish if some of the assumptions of the classical regression model have been violated. That is, the null hypothesis that the errors are both homoskedastic and independent of the regressors, and that the functional form of the model is correct. A non-significant test statistic of 0.371 implies that none of these three conditions is violated. The empirical results are presented next.

\section{Results and Discussion}

The market wide hedonic model was estimated for 126 tenements employed in this study and includes all tenements within $5.5 \mathrm{~km}$ of the cement factory. Before turning to the interpretation of the results, a structural change occurred in the estimated implicit tenement rents of the market wide hedonic model after the $38^{\text {th }}$ observation as seen in fig.2. Therefore the rental data were split into two such that two unrestricted models (the first consisting of 38 tenements within $2.5 \mathrm{~km}$ of the factory and the other comprising 88 tenements located between $2.5 \mathrm{~km}$ to $5.5 \mathrm{~km}$ of the factory respectively) were also estimated.

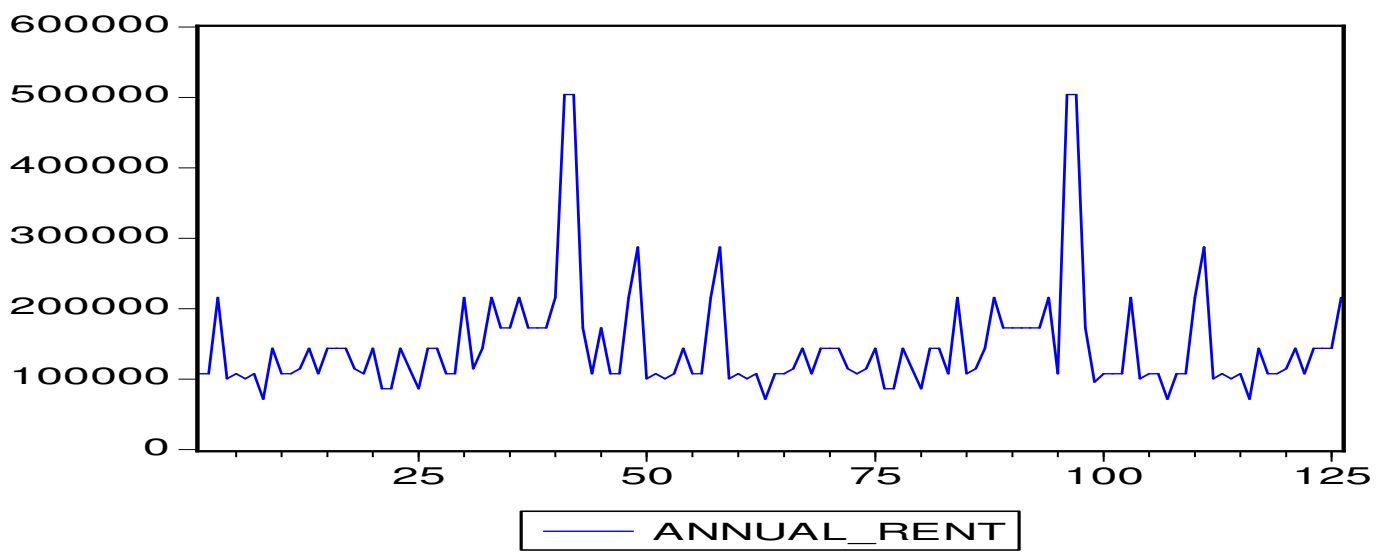

Figure 2: Annual Rent of the 126 Tenements in the Study Area. 
The results of the hedonic models (market wide and the two unrestricted) are presented in Table 3. The 3 models have a good predictive power for the explanatory variables $\left(R^{2}=0.540\right.$ for the market-wide model, $\mathrm{R}^{2}=0.726$ for the unrestricted model 1 and $\mathrm{R}^{2}=0.678$ the unrestricted model 2). Following Johnston and DiNardo (1997), the Durbin-Watson statistics of $1.74-1.93$ for the 3 models which are close to 2.00 suggest that there is no serial correlation in the residuals of the estimated hedonic equations. The F-statistic of 15.105 shows that at $5 \%$ level, the market-wide hedonic equation is statistically significant. The market-wide model reveals that variables such as external wall condition (EXTERNAL_WALL_CONDN), foundation condition (FOUNDN_CODN), age of property (AGE), dust level (DUST_LEVEL), house distance to factory (HOUSEDIST_TO_FACTORY) and noise level(NOISE_LEVEL) are significant determinants of rent of tenement properties in the study area. The coefficients of these six (6) variables are significant at 5\% level of significance.

The significantly negative coefficient for the dummy variable which captures external wall condition implies that bad external wall condition decreases tenement rents by $19.65 \%$ $\left(\mathrm{e}^{-0.219}-1\right)$ or $\$ 72515$ in the study area. An increase in age of the property by an additional year also decreases rent by $9.74 \%\left(\mathrm{e}^{-0.102}-1\right)$ or $\$ 1167$.

Table 3: Results of the Hedonic Pricing of the Tenements in the Study Area.

\begin{tabular}{|c|c|c|c|}
\hline Variables & Market Wide Model & Unrestricted Model 1 & Unrestricted Model 2 \\
\hline & $\begin{array}{l}\text { Coefficients of the whole } \\
\text { houses within } 5.5 \mathrm{~km} \text { of the } \\
\text { Factory }\end{array}$ & 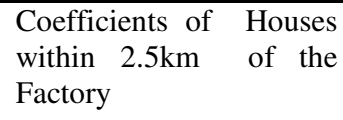 & $\begin{array}{l}\text { Coefficients of Houses } \\
\text { between } 2.5 \mathrm{~km} \text { and } \\
5.5 \mathrm{~km} \text { of the Factory }\end{array}$ \\
\hline CONSTANT & $\begin{array}{l}14.300 \\
(26.00)\end{array}$ & $\begin{array}{l}13.098 \\
(15.673)\end{array}$ & $\begin{array}{l}14.853 \\
(20.411)\end{array}$ \\
\hline EXTERNAL_WALL_CONDN & $\begin{array}{l}-0.219 \\
(-4.81)^{*}\end{array}$ & $\begin{array}{l}-0.292 \\
(-1.887)\end{array}$ & $\begin{array}{l}-0.068 \\
(-1.189)\end{array}$ \\
\hline FOUNDN_CODN & $\begin{array}{l}0.356 \\
(7.78)^{*}\end{array}$ & $\begin{array}{l}0.562 \\
(8.083)^{*}\end{array}$ & $\begin{array}{l}0.291 \\
(6.107)^{*}\end{array}$ \\
\hline ROOF_CONDN & $\begin{array}{l}-0.0353 \\
(-0.768)\end{array}$ & $\begin{array}{l}-0.125 \\
(-1.517)\end{array}$ & $\begin{array}{l}-0.006 \\
(-0.122)\end{array}$ \\
\hline AGE & $\begin{array}{l}-0.102 \\
(-2.035)^{*}\end{array}$ & $\begin{array}{l}0.082 \\
(0.446)\end{array}$ & $\begin{array}{l}-0.142 \\
(-2.082)^{*}\end{array}$ \\
\hline BLD_AREA & $\begin{array}{l}-0.131 \\
(-1.692) * *\end{array}$ & $\begin{array}{l}0.544 \\
(2.064)^{*}\end{array}$ & $\begin{array}{l}-0.199 \\
(-1.676)\end{array}$ \\
\hline DUST_LEVEL & $\begin{array}{l}-0.247 \\
(-4.294)^{*}\end{array}$ & $\begin{array}{l}-0.558 \\
(-3.720)^{*}\end{array}$ & $\begin{array}{l}-0.183 \\
(-3.482)^{*}\end{array}$ \\
\hline HOUSEDIST_TO_FACTORY & $\begin{array}{l}-0.239 \\
(-4.063)^{*}\end{array}$ & $\begin{array}{l}1.153 \\
(3.212)^{*}\end{array}$ & $\begin{array}{l}-0.314 \\
(-6.975) *\end{array}$ \\
\hline OCCUPATION & $\begin{array}{l}-0.081 \\
(-1.353)\end{array}$ & $\begin{array}{l}-0.840 \\
(-1.997)\end{array}$ & $\begin{array}{l}-0.294 \\
(-5.284)^{*}\end{array}$ \\
\hline NOISE_LEVEL & $\begin{array}{l}-0.015 \\
(-9.237)^{*}\end{array}$ & $\begin{array}{l}-0.041 \\
(-2.121)^{*}\end{array}$ & $\begin{array}{l}-0.014 \\
(-8.942)^{*}\end{array}$ \\
\hline $\mathrm{R}^{2}$ & 0.540 & 0.726 & 0.678 \\
\hline Adjusted $\mathrm{R}^{2}$ & 0.504 & 0.638 & 0.641 \\
\hline Standard Error(SE) & 0.269 & 0.223 & 0.233 \\
\hline $\begin{array}{l}\text { RSS } \\
\text { Durbin-Watson } \\
\text { F-Statistic }\end{array}$ & $\begin{array}{l}8.395 \\
1.93 \\
15.105\end{array}$ & $\begin{array}{l}1.40 \\
1.74 \\
8.242\end{array}$ & $\begin{array}{l}4.222 \\
1.87 \\
18.272\end{array}$ \\
\hline No. of Observations & 126 & 38 & 88 \\
\hline
\end{tabular}

* denotes that the coefficient estimates are significant at 5\% level and ** denotes a $10 \%$ level of significance. The $\mathrm{t}$-statistic for the individual coefficient is reported in bracket.

For tenements located near Lafarge cement factory, rents decrease by $21.22 \%$ or $\$ 10727$ based on 2011 rental price. Negative externalities (dust and noise level), within the study area dampen rent by $21.90 \%$ ( $\$ 13815$ ) and $1.49 \%$ ( $\$ 24.80$ ) respectively. The results of the dust level (DUST_LEVEL) and external wall condition (EXTERNAL_WALL_CONDN) are not too surprising given that dust from Lafarge cement factory impact severely on external wall 
condition of most housing units in the study area.

Turning to the two (2) unrestricted models, the signs and magnitude of the coefficients also yield fairly similar results with the market wide model. Interestingly, noise and dust from Lafarge cement factory has a negative impact on tenement rents for houses up to 5.5 kilometres of the factory. The distance points at which such impact tend to fizzle out on house rents is garnered from these two unrestricted models.

A tenement home located within 2.5 kilometers of the cement factory could suffer a reduction in rent of up to $42 \%$ (40260) and $4 \%$ ( 60.90) due to dust fall and severity of noise respectively (see the unrestricted model 1$)^{1}$ while the rent of a tenement property located between 2.5 and 5.5 kilometres from the cement factory could decrease by around $16.7 \%$ ( $\$ 9283)$ and $1.4 \%$ ( $\$ 24.45)$ respectively (as seen in unrestricted model 2) from these two negative externalities. This signifies that house rents tend to decrease with increasing distance to Lafarge cement factory due to severity of dust and noise.

This result is acceptable based on the chow test which provides evidence on price equality in the coefficients of the two unrestricted models. On this basis the null hypothesis of price equality between the unrestricted models implicit price coefficients is rejected at $5 \%$ level of significance since the F-test statistic of 5.92 is greater, when compared with a $5 \%, \mathrm{~F}(9$, 126). In other words, severity of noise and dust level impact on rents of tenements within $2.5 \mathrm{~km}$ and those between $2.5 \mathrm{~km}$ and $5.5 \mathrm{~km}$ of the factory to the extent that they are significantly different.

\section{Conclusion}

This paper has employed hedonic model to examine the impact of Noise and Dust Level on Rental Price of Residential Tenements in Ewekoro, Nigeria. The results presented in this paper suggest among others that noise and dust level are significant predictors of housing rent which is by extension a proxy and impact on house price. Generally, dust and noise level, which are negative externalities from the cement factory dampen rent by $21.90 \%$ ( $\$ 13815)$ and $1.49 \% \quad(\$ 24.80)$ respectively

\footnotetext{
${ }^{1}$ The percentage decrease in rent resulting from change in dust level is derived from the exponent of the coefficient of DUST_LEVEL: $\left(\mathrm{e}^{-0.558}-1\right)$. Other percentage changes are calculated in similar manner.
}

within the study area. The result further signifies that tenement rents tend to decrease with increasing distance to Lafarge cement factory due to severity of dust and noise. These findings are important in all ramifications. Aside the vulnerability of the inhabitants of the eleven communities (especially those in close proximity to the cement factory) to health related hazards, the severity of dust and noise has far-fetched implications on the socioeconomic development of the study area. Undoubtedly the poor quality of existing residential property stock as depict by its external appearance is a reflection of the quality of life of the residents in Ewekoro town which impact on the immediate environment.

\section{Recommendation}

In order to mitigate the negative effects of noise and dust level from cement manufacturing on the immediate residential settlements in the study area, certain precautionary measures must be taken by both the government and cement manufacturing companies. A key consideration regarding government's role is to provide policy response. The obvious policy response is the introduction of effluent fees which would force the cement and other manufacturing companies to internalize their externalities by paying for noise and dust pollution. The imposition of such fees would make it compulsory for cement manufacturing and allied companies to take all necessary precautions in their operations that will prevent or minimize such negative environmental effects. The basic objective of such policy response is for manufacturing companies to move to the use of energy efficient and ecofriendly plants that generate less noise and dust in their production operations. It is instructive to mention however that for such policy to be workable and efficiently abate noise and dust, strengthening of such agency as Environmental Protection Agency at the state level in terms of its capacity building to discharge its responsibilities must be considered. Finally, the cement manufacturing company should imbibe Corporate Social Responsibility (CSR) as part of its efforts in providing a sustainable living environment for the residents.

\section{References}

Benjamin, J. D. and Sirmans, G. S. (1996). Mass transportation, apartment rent and property values. Journal of Real Estate Research, 12(1): 1-8. 
Boyle, M.A., and Kiel, K.A. (2001). A survey of house price hedonic studies of the impact of environmental externalities. Journal of Real Estate Literature, 9(2): 116-144.

Brooks, C. (2008). Introductory econometrics for finance. 2nd ed. New York: Cambridge University Press.

Gujarati, D. N. (2003). Basic econometrics. 4th ed. New York: McGraw-Hill.

Hutchison, N.E. (1994). Housing as an investment? a comparison of returns from housing with other types of investment. Journal of Property Finance, 5(2): 47.

Johnston, J. and DiNardo, J.E. (1997). Econometric Methods, 4th Edition, New York: McGraw-Hill.

Leggett, C. G. and Bockstael, N. E. (2000). Evidence of the effects of water quality on residential land prices. Journal of Environmental Economics and Management, 39(2): 121-144.

Ling, D.C. and Archer, W.R. (2005). Real estate principle: a value approach. US: McGraw-Hill Inc.,

Louw, E., Needham B., Olden H. and Pen, C.J. (2003). Planning van Bedrijventerreinen. Den Haag: SduUitgevers (in Dutch).

Louw, E., Krabben, E. and van der Priemus, H. (2004). Spatial development policy: changing roles for local and regional authorities in the Netherlands. Land Use Policy, 20: 357-366.

Meteorological Department Abeokuta. (2011). Weather forecast.
O'Byrne, P. H., Nelson, J. P. and Seneca, J. J. (1985). Housing values, census estimates, disequilibrium, and the environmental costs of airport noise: a case study of Atlanta. Journal of Environmental Economics and Management, 12(2): 169-178.

Palmquist, R. B. (1982). Estimating the demand for air quality from property value studies.Unpublished paper, Department of Economics and Business, North Carolina State University, Raleigh, NC.

Palmquist, R. B. (1983). Estimating the demand for air quality from property value studies: Further Results, Unpublished paper, Department of Economics and Business, North Carolina State University, Raleigh, NC.

Rosen, S. (1974). Hedonic prices and implicit markets: product differentiation in pure competition, Journal of Political Economy, 82(1): 35-55.

Thayer, M., Albers, H. and Rahmatian, M. (1992). The benefits of reducing exposure to waste disposal sites: a hedonic housing value approach. Journal of Real Estate Research, 7(3): 265-282.

White, H. (1980). A heteroskedasticityconsistent covariance matrix and a direct test for heteroskedasticity. Econometrica, 48: 817-838.

Zabel, J. E. and Kiel, K. A. (2000). Estimating the demand for air quality in four U.S. cities. Land Economics, 76(2): 174-194. 